\title{
Perancangan Sistem Pendukung Keputusan Pemilihan Pengesub Menggunakan TOPSIS
}

\author{
Harliana \\ STIKOM Poltek Cirebon \\ E-mail: harliana.merdiharto@gmail.com
}

\begin{abstract}
Abstrak
Pengambilan keputusan pada suatu perusahaan furniture rattan merupakan suatu hal yang sangat penting. Seorang pimpinan perusahaan furniture rattan seharusnya mengambil sebuah keputusan berdasarkan perhitungan dan pemikiran yang matang agar keputusan pemilihan pengesub (pekerja) yang telah atau akan diambil tidak menimbulkan kesan negatif atau bahkan kerugian terhadap perusahaan yang dipimpinnya. Saat ini perusahaan furniture rattan menggunakan 2 tipe pengesub, yaitu pengesub internal dan pengesub eksternal. Saat ini proses penentuan pemilihan pengesub, khususnya pengesub eksternal masih dilakukan secara manual melalui proses survey langsung. Selain itu faktor kedekatan pengesub dengan para pimpinan perusahaan furniture rattan juga masih menjadi permasalahan klasik. Kendala lain yang sering ditemui yaitu adanya ketidak konsistensian perusahaan furniture rattan dalam menentukan kriteria standar sebagai dasar pertimbangan pemilihan pengesub terbaik. Setelah melakukan pengujian pada 10 alternativ dengan 9 kriteria didapatkan pengesub Andi menempati urutan pertama dengan nilai preferensi relatif untuk setiap alternative adalah 0,5874. Pengesub Eko menempati urutan kedua dengan nilai preferensi relative 0,5801. Ketiga pengesub Gugun (0,4714), Keempat pengesub Bambang (0,4417), Kelima pengesub Kodir (0,4324), Keenam pengesub Tono (0,4166), Ketujuh pengesub Yana (0,3651). Kedelapan pengesub Dedi (0,3466). Kesembilan pengesub Budi (0,2791). Dan terakhir pengesub Opik dengan nilai preferensi relatif $0,1576$.
\end{abstract}

Kata Kunci - Pengesub, SPK, TOPSIS

\begin{abstract}
Decision-making on a rattan furniture company is a very important thing. A rattan furniture company leadership should take a decision based on the calculation and careful thought that pengesub selection decisions (workers) that have been or will be taken not to cause a negative impression or even loss of the company he leads. The company currently uses two types of rattan furniture pengesub, namely pengesub internal and external pengesub. Currently the process of determining the election pengesub, especially external pengesub still done manually through direct survey process. In addition to the proximity factor pengesub leaders rattan furniture company also remains a classic problem. Another problem often encountered is the presence of inconsistencies rattan furniture company in determining the criteria for the selection of a standard as a basis for consideration of best pengesub. After testing at 10 alternativ with 9 criteria obtained pengesub Andi ranks first with a relative preference value for each alternative is 0,5874. Eko Pengesub ranks second with a value of 0,5801 relative preference. Third pengesub Gugun (0,4714), Fourth pengesub Bambang (0,4417), Fifth pengesub Kodir (0.4324), Sixth pengesub Tono (0,4166), Seventh pengesub Yana $(0,3651)$. Eighth pengesub Smith (0,3466), Ninth pengesub Budi (0.2791). And last pengesub Opik with relative preference value 0.1576
\end{abstract}

Keywords - Pengesub, DSS, TOPSIS 


\section{PENDAHULUAN}

Pengesub merupakan salah satu istilah yang digunakan oleh perusahaan furniture rattan di Cirebon untuk menyebutkan para pekerjanya. Dimana dalam memproduksi barangnya, suatu perusahaan furniture rattan biasa menggunakan 2 tipe pengesub yaitu pengesub internal dan pengesub eksternal. Pengesub internal adalah sebutan untuk para pekerja yang bekerja di dalam lingkungan perusahaan rattan tersebut. Pengesub internal dapat di gambarkan sebagai pengesub inti perusahaan rattan, karena mengerjakan semua order didalam lingkungan perusahaan rattan. Sedangkan pengesub eksternal adalah sebutan untuk pekerja yang bekerja diluar lingkungan perusahaan rattan. Pengesub eksternal biasanya merupakan suatu home industri yang bekerjasama dengan perusahaan furniture rattan.

Kemampuan pengesub internal dan eksternal pastilah berbeda, hal ini dapat dilihat pada pembagian pengerjaan order yang diberikan oleh perusahaan furniture rattan terhadap keduanya. Pengesub internal akan mengerjakan order sesuai dengan jenis bahan baku yang dimiliki oleh perusahaan furniture rattan dengan model-model yang relatif mudah dan sedang. Sedangkan pengesub eksternal umumnya akan mengerjakan order jika perusahaan furniture rattan tersebut tidak memiliki ataupun kekurangan bahan baku untuk orderan suatu produk.

Saat ini proses penentuan pemilihan pengesub, khususnya pengesub eksternal masih dilakukan secara manual dengan beberapa kendala dan cenderung memerlukan waktu yang ralatif lama. Hal ini disebabkan karena proses survey langsung yang dilakukan pihak perusahaan furniture rattan dalam menyeleksi pengesub terbaik. Selain itu faktor kedekatan pengesub dengan para pimpinan perusahaan furniture rattan juga masih menjadi permasalahan klasik. Pengesub yang memiliki kedekatan, baik karena faktor keluarga ataupun lainnya, akan mendapatkan pengerjaan order yang lebih banyak bila dibandingkan dengan yang lain meskipun hasil pengerjaannya kurang memuaskan. Selain 2 faktor tersebut, kendala lain yang sering ditemui yaitu adanya ketidak konsistensian perusahaan furniture rattan dalam menentukan kriteria standar pengesub sebagai dasar pertimbangan pemilihan pengesub terbaik. Menyikapi hal tersebut diatas, pada penelitian ini penyusun berusaha untuk membantu perusahaan furniture rattan untuk menentukan pengesub terbaik melalui perangkingan dengan menggunakan metde TOPSIS.

Beberapa penelitian terdahulu yang telah dilakukan sebelumnya dan menjadi referensi penelitian ini adalah: Penelitian [1] melakukan penelitian untuk pemilihan guru berpestasi melalui kriteria penilaian portofolio, ter tertulis, tes kepribadian, wawancara, pembuatan makalah dan presentasi. Penelitian ini menggunakan 2 metode untuk mendapatkan perangkingan guru berprestasi, yaitu metode AHP (Analitycal Hirarchy Process) untuk pembobotan kriteria dan uji tingkat konsistensi terhadap matriks perbandingan berpasangan. Jika matriks telah konsisten maka dapat dilanjutkan ke proses metode TOPSIS dalam melakukan perangkingan untuk menentukan alternatif terpilih dengan menggunakan input bobot kriteria yang diperoleh dari metode AHP. Hasil dari penelitian ini menunjukkan perangkingan guru berprestasi dengan metode AHP dan TOPSIS memiliki perbedaan posisi perangkingan yang sangat signifikan dengan metode yang digunakan oleh pihak Dinas terkait. Dimana kesamaan rangking hanya terlihat pada alternatif urutan ke-21 dan alternatif urutan ke-31.

Penelitian [2] membahas mengenai pemilihan penerimaan calon karyawan melalui 3 tahapan tes yaitu tes diferential, tes technical skill, dan tes wawancara. Berdasarkan 7 data sampling yang digunakan oleh penulis, hanya 5 orang calon karyawan yang lolos pada tes diferensial, sedangkan untuk tes technical skill hanya 4 orang calon karyawan yang dinyatakan lulus. Pada tahap wawancara hanya terdapat 3 calon karyawan yang dinyatakn lulus. Nilai preferensi yang lebih besar dari kedua calon karyawan tersebut adalah karyawan yang akan dipilih dan direkomendasikan untuk bergabung dengan institusi.

Sedangkan penelitian [3] mambahas mengenai pemilihan supplier melalui pengukuran kinerja supplier dalam mengoptimalkan biaya dan waktu produksi. Penelitian ini dilakukan di PT Giri Sekar Kedaton Gresik dengan object penelitian supplier bahan baku seperti semen, 
pasir, besi, batu pondasi, dan kayu. Metode entropy digunakan untuk melakukan perhitungan bobot tiap kriteria serta alternatif, sedangkan untuk perangkingan terhadap supplier digunakan metode TOPSIS. Dari hasil penelitian didapat bahwa supplier semen terbaik adalah Koperasi Semen Gresik, sedangkan supplier pasir terbaik adalah UD Lancar Jaya. Untuk supplier besi terbaik adalah Koperasi Semen Gresik, sedangkan supplier batu pondasi terbaik adalah UD Ikhwan Jaya. Dan yang terakhir adalah supplier kayu terbaik adalah UD Sumber Wangi.

\section{METODE PENELITIAN}

\subsection{Perancangan Sistem}

Sistem yang dibangun adalah suatu sistem yang dapat dipakai oleh bagian PPIC (Planing Production Inventory Control) untuk melakukan pemilihan pengesub terbaik. Selain itu sistem ini juga dapat membantu pimpinan perusahaan furniture rattan dalam memberikan reward atau bonus untuk pengesub-pengesub terbaik yang dimiliki. Proses penentuan pengesub terbaik dilihat dari indikator:

1. Peralatan yang dipakai

Peralatan yang dipakai menunjukkan kelengkapan alat yang digunakan pengesub dalam memproduksi order yang diberikan. Semakin banyak peralatan yang digunakan maka semakin baik pengesub tersebut. Umumnya peralatan yang dipakai tersebut adalah: pemotong kayu atau pemotong rattan, amplas mesin, dan sebagainya

2. Jumlah pekerja yang dimiliki.

Jumlah pekerja yang dimiliki menunjukkan kecepatan dan kamahiran pengesub dalam memproduksi order yang diberikan. Umumnya rasio yang digunakan antara peralatan yang dipakai dengan jumlah pekerja adalah 1:1.

3. Jarak pengesub dengan perusahaan

Jarak pengesub dengan perusahaan menunjukkan seberapa dekat lokasi pengesub dengan perusahaan furniture rattan. Semakin dekat lokasi pengesub dengan perusahaan maka semakin sedikit biaya akomodasi yang harus dikeluarkan oleh perusahaan saat mengirim order kepada pengesub.

4. Harga produksi pengesub

Harga produksi yang ditawarkan pengesub merupakan fee yang ditawarkan pengesub dalam memproduksi barang kepada perusahaan furniture rattan.

5. Jumlah cacat hasil produksi

Jumlah cacat hasil produksi merupakan salah satu kriteria penting dalam penentuan pengesub terbaik. Semakin sedikit cacat hasil produksi yang dihasilkan maka semakin baik pengesub tersebut. Selain itu sedikitnya jumlah cacat hasil produksi dapat menunjukkan tingkat kemahiran dan ketelitian pengesub.

6. Jumlah produksi yang dapat diselesaikan

Jumlah produksi yang dapat terselesaikan menunjukkan seberapa konsisten perusahaan dalam pengerjaan suatu order. Rasio standar yang ditentukan oleh perusahaan antara jumlah produksi dengan jumlah cacat hasil produksi adalah 20:1. Dimana 20 hasil produksi yang terselesaikan minimal hanya memiliki 1 order yang cacat.

7. Waktu pengerjaan

Waktu pengerjaan adalah batas waktu yang diberikan perusahaan furniture rattan dalam mengerjakan order. Semakin cepat batas order tersebut selesai sebelum batas waktu yang ditentukan maka semakin baik penilaian perusahaan furniture rattan terhadap pengesub tersebut.

8. Ketersediaan bahan baku

Ketersediaan bahan baku merupakan salah satu point yang menunjukkan kelengkapan bahan baku yang dimiliki oleh pengesub. 
9. Ketepatan waktu pengerjaan order

Ketepatan waktu pengerjaan adalah salah satu kriteria penting dalam penilaian pengesub. Dimana ketepatan waktu pengerjaan order adalah kekonsistensian pengesub dalam mengirimkan order sesuai dengan batas waktu yang telah ditentukan. Batas waktu keterlambatan yang ditolerir perusahaan furniture rattan hanyalah 4 hari terhitung sejak tanggal batas akhir pengiriman.

Gambar 1 menunjukkan gambaran umum dari sistem yang dibuat, dimana sistem akan melakukan proses pengolahan data kriteria, pengolahan data alternatif yang dimiliki serta proses perhitungan perangkingan yang terdiri dari proses perhitungan matrik keputusan ternormalisasi, perhitungan matriks ternormalisasi terbobot, perhitungan matriks solusi ideal, perhitungan jarak tiap alternatif, perhitungan nilai preferensi serta proses perhitungan perangkingan matriks. User yang terlibat dari sistem adalah PPIC sebagai penanggung jawab pelaksana serta pimpinan furniture rattan tersebut sebagai pengawas.

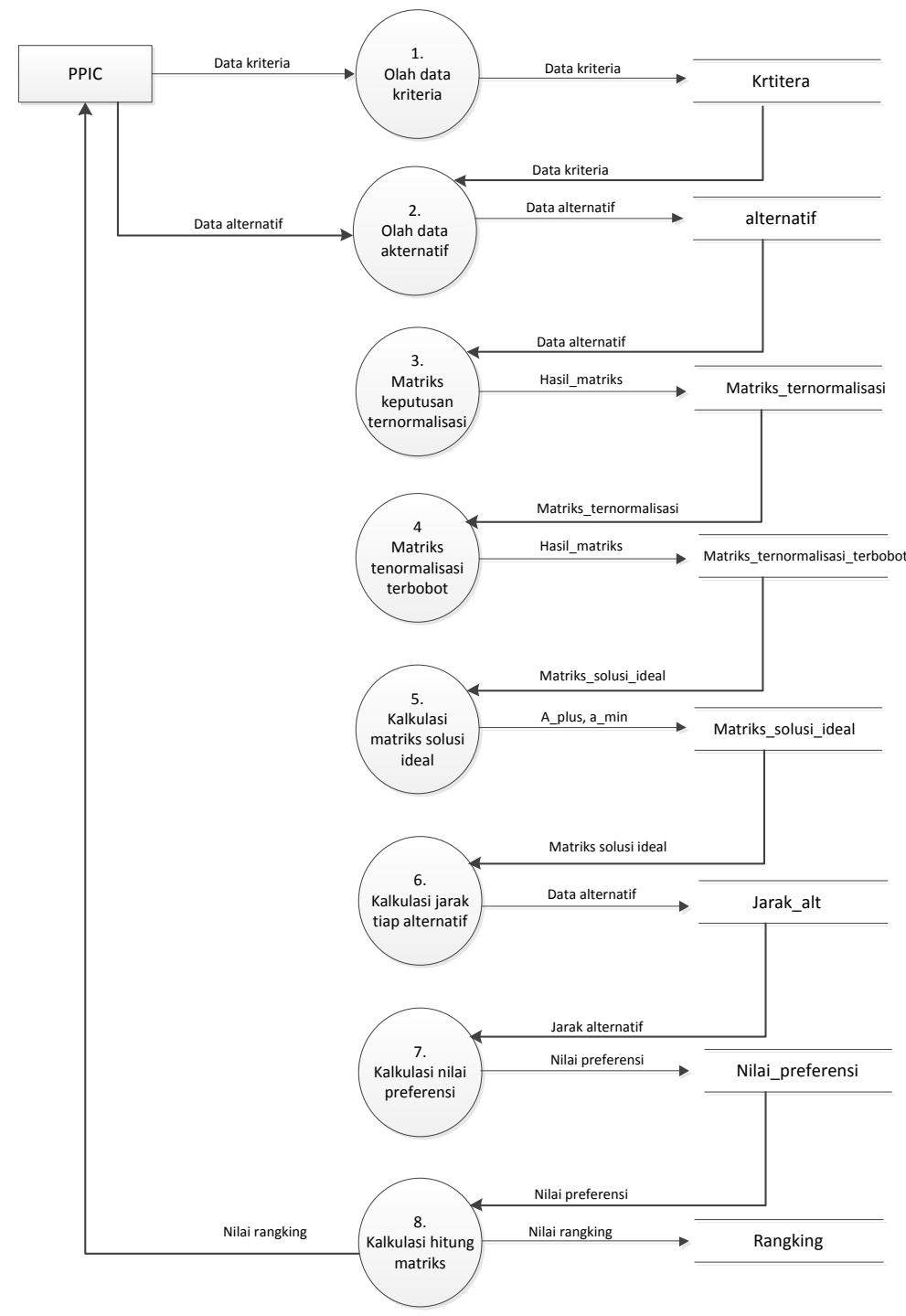

Gambar 1. Proses Perancangan Sistem 


\subsection{Technique for Order Preference by Similarity to Ideal Solution (TOPSIS)}

TOPSIS adalah salah satu metode yang bisa membantu proses pengambilan keputusan yang optimal untuk menyelesaikan masalah keputusan secara praktis. Hal ini disebabkan karena konsepnya sederhana dan mudah dipahami, komputasinya efisien dan memiliki kemampuan untuk mengukur kinerja relatif dari alternatif-alternatif keputusan dalam bentuk matematis sederhana..$^{[4]}$

Secara umum, prosedur TOPSIS mengikuti langkah-langkah sebegai berikut: ${ }^{[4]}$

a. Menentukan matriks keputusan yang ternormalisasi

b. Menghitung matriks keputusan ternormalisasi yang terbobot

c. Menghitung matriks solusi ideal positif dan matriks solusi ideal nagatif

d. Menghitung jarak antara nilai setiap alternatif dengan matriks solusi ideal positif dan matriks solusi ideal negatif

e. Menghitung nilai preferensi untuk setiap alternatif

TOPSIS membutuhkan rating kinerja setiap alternatif $A_{i}$ pada setiap kriteria $C_{j}$ yang ternormalisasi, yaitu:

$$
r_{i j}=\frac{x_{i j}}{\sqrt{\sum_{i=1}^{m} x_{i j}^{2}}} \quad \text { dengan } \mathrm{i}=1,2, \ldots, \mathrm{m} ; \text { dan } \mathrm{j}=1,2, \ldots, \mathrm{n} .
$$

Solusi ideal positif $\mathrm{A}^{+}$dan solusi ideal negatif $\mathrm{A}^{-}$dapat ditentukan berdasarkan rating bobot ternormalisasi $\left(\mathrm{y}_{\mathrm{ij}}\right)$ sebagai:

$$
\begin{array}{cl}
y_{i j}=w_{i} r_{i j} & \text { dengan } \mathrm{i}=1,2, \ldots, \mathrm{m} ; \text { dan } \mathrm{j}=1,2, \ldots, \mathrm{n} . \\
A^{+}=\left(y_{1}^{+}, y_{2}^{+}, \cdots, y_{n}^{+}\right) ; & \\
A^{-}=\left(y_{1}^{-}, y_{2}^{-}, \cdots, y_{n}^{-}\right), &
\end{array}
$$

Dengan

$$
\begin{gathered}
y_{j}^{+}= \begin{cases}\max _{i} y_{i j} ; & j i k a \mathrm{j} \text { adalah atribut keuntungan } \\
\min _{i} y_{i j} ; & \mathrm{jika} \mathrm{j} \text { adalah atribut biaya }\end{cases} \\
\left(\boldsymbol{G}_{j}= \begin{cases}\min _{i} y_{i j} ; & j i k a \mathrm{j} \text { adalah atribut keuntungan } \\
\max _{i} y_{i j} ; & \mathrm{jika} \mathrm{j} \text { adalah atribut biaya }\end{cases} \right.
\end{gathered}
$$

Dimana: $\mathrm{j}=1,2, \ldots, n$. 
Sedangkan jarak antara alternatif $\mathrm{A}_{\mathrm{i}}$ dengan solusi ideal positif dirumuskan sebagai:

$$
D_{i}^{+}=\sqrt{\sum_{j=1}^{n}\left(y_{i}^{+}-y_{i j}\right)^{2}} ; \quad \mathrm{i}=1,2, \ldots, \mathrm{m} .
$$

Jarak antara alternatif $A_{i}$ dengan solusi ideal negatif dirumuskan sebagai:

$$
D_{i}^{-}=\sqrt{\sum_{j=1}^{n}\left(y_{i j}-y_{i}^{-}\right)^{2}} ; \quad \mathrm{i}=1,2, \ldots, \mathrm{m} .
$$

Nilai preferensi untuk setiap alternatif $\left(\mathrm{V}_{\mathrm{i}}\right)$ diberikan sebagai:

$$
V_{i}=\frac{D_{i}^{-}}{D_{i}^{-}+D_{i}^{+}} ;
$$

Nilai $V_{i}$ yang lebih besar menunjukkan bahwa alternatif $A_{i}$ lebih dipilih

\section{HASIL DAN PEMBAHASAN}

Sample yang digunakan dalam proses perangkingan pemilihan pengesub terbaik dengan metode TOPSIS menggunakan 10 alternatif. Prosedur perhitungan yang dilakukan adalah:

1. Menentukan nilai relatif terhadap masing-masing alternatif

\begin{tabular}{|c|c|c|c|c|c|c|c|c|c|}
\hline \multirow{2}{*}{$\begin{array}{l}\text { Pengesub } \\
\text { (Alternativ) }\end{array}$} & \multicolumn{9}{|c|}{ Kriteria } \\
\hline & $\begin{array}{l}\text { Peralatan } \\
\text { Yang } \\
\text { Dipakai }\end{array}$ & $\begin{array}{l}\text { Jumlah } \\
\text { Pekerja }\end{array}$ & $\begin{array}{l}\text { Jarak } \\
\text { Pengesub }\end{array}$ & $\begin{array}{l}\text { Harga } \\
\text { Produksi }\end{array}$ & $\begin{array}{l}\text { Jumlah } \\
\text { Cacat }\end{array}$ & $\begin{array}{l}\text { Jumlah } \\
\text { Produksi }\end{array}$ & $\begin{array}{l}\text { Waktu } \\
\text { Pengerjaan }\end{array}$ & $\begin{array}{l}\text { Ketersediaan } \\
\text { Bahan Baku }\end{array}$ & \begin{tabular}{|l|} 
Ketepatan \\
Waktu \\
Pengiriman \\
\end{tabular} \\
\hline Bambang & 4 & 4 & 150 & 900.000 & 4 & 25 & 8 & 1 & 1 \\
\hline Eko & 11 & 11 & 250 & 1.500 .000 & 2 & 22 & 15 & 3 & 2 \\
\hline Dedi & 15 & 15 & 370 & 2.500 .000 & 2 & 30 & 10 & 1 & 1 \\
\hline Gugun & 20 & 20 & 500 & 3.500 .000 & 1 & 10 & 7 & 7 & 0 \\
\hline Opik & 4 & 4 & 150 & 900.000 & 1 & 11 & 5 & 3 & 0 \\
\hline Yana & 11 & 11 & 250 & 1.500 .000 & 1 & 7 & 10 & 7 & 0 \\
\hline Kodir & 15 & 15 & 370 & 2.500 .000 & 1 & 10 & 15 & 1 & 1 \\
\hline Andi & 20 & 20 & 500 & 3.500 .000 & 1 & 5 & 10 & 4 & 2 \\
\hline Tono & 4 & 4 & 150 & 900.000 & 1 & 11 & 11 & 7 & 1 \\
\hline Budi & 11 & 11 & 250 & 1.500 .000 & 1 & 8 & 5 & 5 & 0 \\
\hline
\end{tabular}

Sample perhitungan untuk masing-masing pengesub dapat dilihat pada Tabel 1.

Tabel 1. Nilai alternatif terhadap masing-masing kriteria 
Citec Journal, Vol. 1, No. 2, Februari 2014 - April 2014

ISSN: 2354-5771

2. Menentukan matriks keputusan ternormalisasi

Dalam menentukan matrik keputusan ternormalisasi, nilai tiap kriteria $\left(\mathrm{x}_{\mathrm{ij}}\right)$ untuk keseluruhan alternatif dijumlahkan kemudian nilai masing-masing kriteria tersebut dibagi dengan hasil jumlah kriterianya.

a. Untuk kriteria peralatan yang dipakai $\left(\mathrm{C}_{1}\right)$

$$
\begin{aligned}
\left|\mathrm{C}_{1}\right| & =\sqrt{(4)^{2}+(11)^{2}+(15)^{2}+(20)^{2}+(4)^{2}+(11)^{2}+(15)^{2}+(20)^{2}+(4)^{2}+(11)^{2}} \\
& =40,7554
\end{aligned}
$$

\begin{tabular}{|c|c|c|c|c|c|c|c|c|c|}
\hline \multirow{2}{*}{$\begin{array}{l}\text { Pengesub } \\
\text { (Alternativ) }\end{array}$} & \multicolumn{9}{|c|}{ Kriteria } \\
\hline & $\begin{array}{l}\text { Peralatan } \\
\text { Yang } \\
\text { Dipakai }\end{array}$ & $\begin{array}{l}\text { Jumlah } \\
\text { Pekerja }\end{array}$ & $\begin{array}{l}\text { Jarak } \\
\text { Pengesub }\end{array}$ & $\begin{array}{l}\text { Harga } \\
\text { Produksi }\end{array}$ & $\begin{array}{l}\text { Jumlah } \\
\text { Cacat }\end{array}$ & $\begin{array}{l}\text { Jumlah } \\
\text { Produksi }\end{array}$ & $\begin{array}{l}\text { Waktu } \\
\text { Pengerjaan }\end{array}$ & $\begin{array}{l}\text { Ketersediaan } \\
\text { Bahan Baku }\end{array}$ & $\begin{array}{l}\text { Ketepatan } \\
\text { Waktu } \\
\text { Pengiriman }\end{array}$ \\
\hline Bambang & 0,0981 & 0,0981 & 0,1479 & 0,1324 & 0,7184 & 0,4913 & 0,2488 & 0,0692 & 0,2887 \\
\hline Eko & 0,2699 & 0,2699 & 0,2465 & 0,2207 & 0,3592 & 0,4324 & 0,4665 & 0,2075 & 0,5774 \\
\hline Dedi & 0,3680 & 0,3680 & 0,3648 & 0,3679 & 0,3592 & 0,5896 & 0,3110 & 0,0692 & 0,2887 \\
\hline Gugun & 0,4907 & 0,4907 & 0,4930 & 0,5150 & 0,1796 & 0,1965 & 0,2177 & 0,4842 & 0,0000 \\
\hline
\end{tabular}

b. Untuk kriteria jumlah pekerja yang dimiliki $\left(\mathrm{C}_{2}\right)$

$$
\begin{aligned}
& \left|C_{2}\right|=\sqrt{(4)^{2}+(11)^{2}+(15)^{2}+(20)^{2}+(4)^{2}+(11)^{2}+(15)^{2}+(20)^{2}+(4)^{2}+(11)^{2}} \\
& =40,7554 \\
& \mathrm{R}_{12}=\mathrm{X}_{12} / \mathrm{C}_{2}=4 / 40,7554 \quad=\quad 0,0981 \\
& \mathrm{R}_{22}=\mathrm{X}_{22} / \mathrm{C}_{2}=11 / 40,7554=0,2699 \\
& \mathrm{R}_{32}=\mathrm{X}_{32} / \mathrm{C}_{2}=15 / 40,7554=0,3680 \\
& \mathrm{R}_{42}=\mathrm{X}_{42} / \mathrm{C}_{2}=20 / 40,7554=0,4907 \\
& \mathrm{R}_{52}=\mathrm{X}_{52} / \mathrm{C}_{2}=4 / 40,7554 \quad=\quad 0,0981 \\
& \mathrm{R}_{62}=\mathrm{X}_{62} / \mathrm{C}_{2}=11 / 40,7554=0,2699 \\
& \mathrm{R}_{72}=\mathrm{X}_{72} / \mathrm{C}_{2}=15 / 40,7554=0,3680 \\
& \mathrm{R}_{82}=\mathrm{X}_{82} / \mathrm{C}_{2}=20 / 40,7554=0,4907 \\
& \mathrm{R}_{92}=\mathrm{X}_{92} / \mathrm{C}_{2}=4 / 40,7554=0,0981 \\
& \mathrm{R}_{102}=\mathrm{X}_{102} / \mathrm{C}_{2}=11 / 40,7554=0,2699
\end{aligned}
$$

Dan seterusnya, hingga didapatkan Tabel 2.

Tabel 2. Matrik Ternormalisasi 
Tabel 2. Lanjutan

\begin{tabular}{|l|c|c|c|c|c|c|c|c|c|}
\hline Opik & 0,0981 & 0,0981 & 0,1479 & 0,1324 & 0,1796 & 0,2162 & 0,1555 & 0,2075 & 0,0000 \\
\hline Yana & 0,2699 & 0,2699 & 0,2465 & 0,2207 & 0,1796 & 0,1376 & 0,3110 & 0,4842 & 0,0000 \\
\hline Kodir & 0,3680 & 0,3680 & 0,3648 & 0,3679 & 0,1796 & 0,1965 & 0,4665 & 0,0692 & 0,2887 \\
\hline Andi & 0,4907 & 0,4907 & 0,4930 & 0,5150 & 0,1796 & 0,0983 & 0,3110 & 0,2767 & 0,5774 \\
\hline Tono & 0,0981 & 0,0981 & 0,1479 & 0,1324 & 0,1796 & 0,2162 & 0,3421 & 0,4842 & 0,2887 \\
\hline Budi & 0,2699 & 0,2699 & 0,2465 & 0,2207 & 0,1796 & 0,1572 & 0,1555 & 0,3459 & 0,0000 \\
\hline
\end{tabular}

3. Menentukan matriks keputusan normalisasi terbobot

Sebelum menghitung matrik keputusan normalisasi terbobot, tentukan terlebih dahulu bobot dari masing-masing kriteria. Tingkat kepentingan tiap kriteria dapat dinilai dari range 1 sampai 5, yaitu:

1 : tidak penting

2 : tidak terlalu penting

3 : cukup penting

4 : penting

5 : sangat penting

Nilai bobot awal (w) digunakan untuk menunjukkan tingkat kepentingan relatif dari setiap kriteria. Bobot dari masing-masing kriteria tertera pada Tabel 3.

Tabel 3. Bobot Kriteria

\begin{tabular}{|c|l|c|}
\hline No & \multicolumn{1}{|c|}{ Kriteria } & Bobot $(\mathbf{W})$ \\
\hline 1 & Peralatan yang dipakai & 3 \\
\hline 2 & Jumlah pekerja yang dimiliki & 3 \\
\hline 3 & Jarak pengesub dengan perusahaan & 3 \\
\hline 4 & Harga produksi & 5 \\
\hline 5 & Jumlah cacat hasil produksi & 4 \\
\hline 6 & Jumlah produksi & 4 \\
\hline 7 & Waktu pengerjaan & 5 \\
\hline 8 & Ketersediaan bahan baku & 5 \\
\hline 9 & Ketepatan waktu pengiriman & 5 \\
\hline
\end{tabular}

Setelah menentukan bobot dari masing-masing kriteria, maka berdasarkan langkah 1 dan persamaan 2, kita dapat menghitung matrik normalisasi terbobot yaitu:

a. Untuk kriteria peralatan yang dipakai

$\mathrm{Y} 11=\mathrm{W} 11 / \mathrm{R} 11=3 / 0,0981=0,2944$

$\mathrm{Y} 21=\mathrm{W} 11 / \mathrm{R} 21=3 / 0,2699=0,8097$

$\mathrm{Y} 31=\mathrm{W} 11 / \mathrm{R} 31=3 / 0,3680=1,1041$

$\mathrm{Y} 41=\mathrm{W} 11 / \mathrm{R} 41=3 / 0,4907=1,4722$

$\mathrm{Y} 51=\mathrm{W} 11 / \mathrm{R} 51=3 / 0,0981=0,2944$

$\mathrm{Y} 61=\mathrm{W} 11 / \mathrm{R} 61=3 / 0,2699=0,8097$

$\mathrm{Y} 71=\mathrm{W} 11 / \mathrm{R} 71=3 / 0,3680=1,1041$

$\mathrm{Y} 81=\mathrm{W} 11 / \mathrm{R} 81=3 / 0,4907=1,4722$

$\mathrm{Y} 91=\mathrm{W} 11 / \mathrm{R} 31=3 / 0,0981=0,2944$

$\mathrm{Y} 101=\mathrm{W} 11 / \mathrm{R} 31=3 / 0,2699=0,8097$ 
Citec Journal, Vol. 1, No. 2, Februari 2014 - April 2014

b. Untuk kriteria jumlah pekerja yang dimiliki

$$
\begin{aligned}
& \mathrm{Y} 12=\mathrm{W} 21 / \mathrm{R} 12=3 / 0,0981=0,2944 \\
& \mathrm{Y} 22=\mathrm{W} 21 / \mathrm{R} 22=3 / 0,2699=0,8097 \\
& \mathrm{Y} 32=\mathrm{W} 21 / \mathrm{R} 32=3 / 0,3680=1,1041 \\
& \mathrm{Y} 42=\mathrm{W} 21 / \mathrm{R} 42=3 / 0,4907=1,4722 \\
& \mathrm{Y} 52=\mathrm{W} 21 / \mathrm{R} 52=3 / 0,0981=0,2944 \\
& \mathrm{Y} 62=\mathrm{W} 21 / \mathrm{R} 62=3 / 0,2699=0,8097 \\
& \mathrm{Y} 72=\mathrm{W} 21 / \mathrm{R} 72=3 / 0,3680=1,1041 \\
& \mathrm{Y} 82=\mathrm{W} 21 / \mathrm{R} 82=3 / 0,4907=1,4722 \\
& \mathrm{Y} 92=\mathrm{W} 21 / \mathrm{R} 92=3 / 0,0981=0,2944 \\
& \mathrm{Y} 102=\mathrm{W} 21 / \mathrm{R} 102=3 / 0,2699=0,8097
\end{aligned}
$$

\begin{tabular}{|c|c|c|c|c|c|c|c|c|c|}
\hline \multirow{2}{*}{$\begin{array}{l}\text { Pengesub } \\
\text { (Alternativ) }\end{array}$} & \multicolumn{9}{|c|}{ Kriteria } \\
\hline & $\begin{array}{l}\text { Peralatan } \\
\text { Yang } \\
\text { Dipakai }\end{array}$ & $\begin{array}{l}\text { Jumlah } \\
\text { Pekerja }\end{array}$ & $\begin{array}{l}\text { Jarak } \\
\text { Pengesub }\end{array}$ & $\begin{array}{l}\text { Harga } \\
\text { Produksi }\end{array}$ & $\begin{array}{l}\text { Jumlah } \\
\text { Cacat }\end{array}$ & $\begin{array}{l}\text { Jumlah } \\
\text { Produksi }\end{array}$ & $\begin{array}{l}\text { Waktu } \\
\text { Pengerjaan }\end{array}$ & $\begin{array}{l}\text { Ketersediaan } \\
\text { Bahan Baku }\end{array}$ & $\begin{array}{l}\text { Ketepatan } \\
\text { Waktu } \\
\text { Pengiriman }\end{array}$ \\
\hline Bambang & 0,2944 & 0,2944 & 0,4437 & 0,6622 & 2,8737 & 1,9653 & 1,2439 & 0,3459 & 1,4434 \\
\hline Eko & 0,8097 & 0,8097 & 0,7394 & 1,1037 & 1,4368 & 1,7295 & 2,3324 & 1,0376 & 2,8868 \\
\hline Dedi & 1,1041 & 1,1041 & 1,0944 & 1,1037 & 1,0776 & 1,7688 & 0,9330 & 0,2075 & 0,8660 \\
\hline Gugun & 1,4722 & 1,4722 & 1,4789 & 2,5752 & 0,7184 & 0,7861 & 1,0884 & 2,4210 & 0,0000 \\
\hline Opik & 0,2944 & 0,2944 & 0,4437 & 0,6622 & 0,7184 & 0,8647 & 0,7775 & 1,0376 & 0,0000 \\
\hline Yana & 0,8097 & 0,8097 & 0,7394 & 1,1037 & 0,7184 & 0,5503 & 1,5549 & 2,4210 & 0,0000 \\
\hline Kodir & 1,1041 & 1,1041 & 1,0944 & 1,8394 & 0,7184 & 0,7861 & 2,3324 & 0,3459 & 1,4434 \\
\hline Andi & 1,4722 & 1,4722 & 1,4789 & 2,5752 & 0,7184 & 0,3931 & 1,5549 & 1,3834 & 2,8868 \\
\hline Tono & 0,2944 & 0,2944 & 0,4437 & 0,6622 & 0,7184 & 0,8647 & 1,7104 & 2,4210 & 1,4434 \\
\hline Budi & 0,8097 & 0,8097 & 0,7394 & 1,1037 & 0,7184 & 0,6289 & 0,7775 & 1,7293 & 0,0000 \\
\hline
\end{tabular}

Dan seterusnya, hingga didapatkan nilai pada Tabel 4.

Tabel 4. Matrik normalisasi terbobot

4. Menentukan matriks solusi ideal positif \& matriks solusi ideal negatif Langkah selanjutnya yaitu menentukan matrik solusi ideal positif dan matrik solusi ideal negatif berdasarkan persamaan 3 dan 4 .

Matrik solusi ideal positif $\left(\mathrm{Y}_{\mathrm{ij}}^{+}\right)$:

$\mathrm{Y}_{1}^{+}=\max \{0,2944 ; 0,8097 ; 1,1041 ; 1,4722 ; 0,2944 ; 0,8097 ; 1,1041 ;$ $1,4722 ; 0,2944 ; 0,8097\}=1,4722$

$\mathrm{Y}_{2}^{+}=\max \{0,2944 ; 0,8097 ; 1,1041 ; 1,4722 ; 0,2944 ; 0,8097 ; 1,1041 ;$ $1,4722 ; 0,2944 ; 0,8097\}=1,4722$

$\mathrm{Y}_{3}{ }^{+}=\max \{0,4437 ; 0,7394 ; 1,0944 ; 1,4789 ; 0,4437 ; 0,7394 ; 1,0944$ $1,4789 ; 0,4437 ; 0,7394\}=1,4789$ 
Dan seterusnya sehingga didapatkan:

$\mathrm{A}^{+}=\{1,4722 ; 1,4722 ; 1,4789 ; 2,5752 ; 2,8737 ; 1,9653 ; 2,3343$; $2,4210 ; 2,8868\}$

Sedangkan matrik solusi ideal negatif $\left(\mathrm{Y}_{\mathrm{ij}}{ }^{-}\right)$:

$\mathrm{Y}_{1}{ }^{-}=\min \{0,2944 ; 0,8097 ; 1,1041 ; 1,4722 ; 0,2944 ; 0,8097 ; 1,1041$;

$1,4722 ; 0,2944 ; 0,8097\}=0,2944$

$\mathrm{Y}_{2}^{-}=\min \{0,2944 ; 0,8097 ; 1,1041 ; 1,4722 ; 0,2944 ; 0,8097 ; 1,1041 ;$

$1,4722 ; 0,2944 ; 0,8097\}=0,2944$

$\mathrm{Y}_{3}{ }^{-}=\min \{0,4437 ; 0,7394 ; 1,0944 ; 1,4789 ; 0,4437 ; 0,7394 ; 1,0944$

$1,4789 ; 0,4437 ; 0,7394\}=0,4437$

Dan seterusnya sehingga didapatkan:

$\mathrm{A}^{-}=\{0,2944 ; 0,2944 ; 0,4437 ; 0,6625 ; 0,7184 ; 0,3931 ; 0,7775 ;$

$0,2075 ; 0,0000\}$

5. Menentukan jarak antara nilai setiap alternatif dengan matriks solusi ideal positif \& matriks solusi ideal negatif

Selanjutnya untuk mencari jarak antar alternatif dengan matriks solusi ideal positif dapat menggunakan persamaan 7 .

$$
\begin{aligned}
\mathrm{D}_{1}{ }^{+}= & \sqrt{(0,2944-1,4722)^{2}+(0,2944-1,4722)^{2}+(0,4437-1,4789)^{2}+} \\
& \sqrt{(0,6625-2,5725)^{2}+(2,8737-2,8737)^{2}+(1,9653-1,9653)^{2}} \\
& \sqrt{+(2,3324-1,2439)^{2}+(0,3459-2,4210)^{2}+} \\
& \sqrt{(1,4434-2,8868)^{2}} \\
= & 3,8883 \\
\mathrm{D}_{2}{ }^{+}= & \sqrt{(0,2944-0,8097)^{2}+(0,2944-0,8097)^{2}+(0,4437-0,7394)^{2}+} \\
& \sqrt{(0,6625-1,1037)^{2}+(2,8737-1,4368)^{2}+(1,9653-1,7295)^{2}} \\
& \sqrt{+(2,3324-2,3324)^{2}+(2,4210-1,0376)^{2}+} \\
& \sqrt{(2,8868-2,8868)^{2}} \\
= & 2,7612
\end{aligned}
$$

Dan seterusnya sehingga didapatkan:

$\left\{\mathrm{D}_{1}^{+}, \mathrm{D}_{2}{ }^{+}, \mathrm{D}_{3}{ }^{+}, \mathrm{D}_{4}{ }^{+}, \mathrm{D}_{5}{ }^{+}, \mathrm{D}_{6}{ }^{+}, \mathrm{D}_{7}{ }^{+}, \mathrm{D}_{8}{ }^{+}, \mathrm{D}_{9}{ }^{+}, \mathrm{D}_{10}{ }^{+}\right\}=$

$\{3,8833 ; 2,7612 ; 4,0975 ; 3,9895 ; 5,1017 ; 4,3790 ; 3,6586 ; 2,9662 ; 3,9790 ; 4,6099\}$ 
Citec Journal, Vol. 1, No. 2, Februari 2014 - April 2014

Sedangkan untuk mencari jarak antar alternatif dengan matriks solusi ideal negatif dapat menggunakan persamaan 8 .

$$
\begin{aligned}
\mathrm{D}_{1}{ }^{-}= & \sqrt{(0,2944-0,2944)^{2}+(0,2944-0,2944)^{2}+(0,4437-0,4437)^{2}+} \\
& \sqrt{(0,6625-0,6622)^{2}+(2,8737-6,7184)^{2}+(1,9653-0,3931)^{2}} \\
& \sqrt{+(1,2439-0,7775)^{2}+(0,3459-0,2075)^{2}+} \\
& \sqrt{(1,4434-0)^{2}=} 0,2944 \\
D_{2}{ }^{-}= & \sqrt{(0,8097-0,2944)^{2}+(0,8097-0,2944)^{2}+(0,7394-0,4437)^{2}+} \\
& \sqrt{(1,1037-0,6622)^{2}+(1,4368-6,7184)^{2}+(1,7295-0,3931)^{2}} \\
& \sqrt{+(2,3324-0,7775)^{2}+(1,0376-0,2075)^{2}+} \\
= & \sqrt{(2,8868-0)^{2}}
\end{aligned}
$$

Dan seterusnya sehingga didapatkan:

$\left\{\mathrm{D}_{1}^{-}, \mathrm{D}_{2}^{-}, \mathrm{D}_{3}^{-}, \mathrm{D}_{4}^{-}, \mathrm{D}_{5}^{-}, \mathrm{D}_{6}^{-}, \mathrm{D}_{7}^{-}, \mathrm{D}_{8}^{-}, \mathrm{D}_{9}^{-}, \mathrm{D}_{10^{-}}{ }^{-}\right\}=$ $\{0,2944 ; 0,2944 ; 0,4437 ; 0,6622 ; 0,7184 ; 0,3931 ; 0,7775 ; 0,2075 ; 0\}$

6. Langkah terakhir dalam perhitungan TOPSIS adalah mencari nilai preferensi untuk setiap alternatif diberikan sesuai dengan persamaan 9

a. Nilai preferensi untuk alternatif bambang

$$
\begin{aligned}
\mathrm{V}_{1} & =\frac{\mathrm{D}_{1}{ }^{-}}{\mathrm{D}_{1}{ }^{-}+\mathrm{D}_{1}{ }^{+}} \\
& =\frac{3,0720}{3,0720+3,8883} \\
& =0,4417
\end{aligned}
$$

b. Nilai preferensi untuk alternatif eko

$$
\begin{aligned}
\mathrm{V}_{2} & =\frac{\mathrm{D}_{2}^{-}}{\mathrm{D}_{2}{ }^{-}+\mathrm{D}_{2}{ }^{+}} \\
& =\frac{3,8152}{3,8152+2,7612} \\
& =0,5801
\end{aligned}
$$

Dan seterusnya sampai dengan alternatif budi. Tabel 5 merupakan hasil perhitungan nilai preferensi untuk semua alternatif. 
Tabel 5. Nilai preferensi terhadap alternatif

\begin{tabular}{|c|l|c|}
\hline No & Alternatif & Nilai preferensi \\
\hline 1 & Bambang & 0,4417 \\
\hline 2 & Eko & 0,5801 \\
\hline 3 & Dedi & 0,3466 \\
\hline 4 & Gugun & 0,4714 \\
\hline 5 & Opik & 0,1576 \\
\hline 6 & Yana & 0,3651 \\
\hline 7 & Kodir & 0,4328 \\
\hline 8 & Andi & $\mathbf{0 , 5 8 7 4}$ \\
\hline 9 & Tono & 0,4166 \\
\hline 10 & Budi & 0,2791 \\
\hline
\end{tabular}

Berdasarkan nilai preferensi terbesar 0,5878 maka pengesub Andi adalah pengesub terbaik.

\section{KESIMPULAN}

1. Kriteria dasar yang dapat dijadikan standar pemilihan pengesub untuk pengerjaan order adalah: peralatan yang dipakai pengesub, jumlah pekerja yang dimiliki pengesub, jarak tempuh antara lokasi pengesub dengan perusahaan furniture rattan, harga produksi yang ditawarkan pengesub, jumlah cacat hasil produksi, jumlah produksi yang diberikan, waktu pengerjaan, ketersediaan (kelengkapan) bahan baku pengesub, serta ketepatan waktu pengiriman order yang diberikan oleh perusahaan rattan.

2. Hasil dari perhitungan dengan menggunakan TOPSIS didapatkan pengesub Andi menempati urutan pertama dengan nilai preferensi relatif untuk setiap alternatifnya sebesar 0,5874. Pengesub Eko menempati urutan kedua, dengan nilai preferensi relatifnya adalah 0,5801. Pengesub Gugun dengan urutan ketiga dengan nilai preferensi relatif 0,4714. Pengesub Bambang di urutan keempat dengan nilai preferensi relatif 0,4417. Pengesub Kodir di urutan kelima dengan nilai preferensi relatif 0,4324. Pengesub Tono di urutan keenam dengan nilai preferensi relatifnya 0,4166 . Pengesub Yana di urutan ketujuh dengan nilai preferensi relatif 0,3651 . Pengesub Dedi di urutan kedepalan dengan nilai preferensi relatif 0,3466. Pengesub Budi di urutan ke sembilan dengan nilai preferensi relatif 0,2791. Dan di urutan terakhir adalah pengesub Opik dengan nilai preferensi relatif 0,1576

\section{SARAN}

Saran yang dapat diberikan untuk pengembangan lebih lanjut dari penelitian ini adalah perlu dilakukannya perbandingan hasil perangkingan antara metode TOPSIS dengan metode perangkingan yang lain seperti ELECTREE, AHP dan sebagainya untuk mendapatkan efektifitas hasil perangkingan yang lebih baik

\section{DAFTAR PUSTAKA}

[1] Juliyanti, Irawan, M. I., Mukhlas, I., 2011, Pemilihan Guru Berprestasi Menggunakan Metode AHP dan TOPSIS, Prosiding Seminar Nasional Penelitian Pendidikan dan Penerapan MIPA, Yogyakarta, 14 Mei 2011.

[2] Lestari, S., 2011, Seleksi Penerimaan Calon Karyawan Menggunakan Metode Topsis., Konferensi Nasional Sistem dan Informatika, Bali, 12 November 2011. 
Citec Journal, Vol. 1, No. 2, Februari 2014 - April 2014

ISSN: 2354-5771

[3] Wardhani, I. K., Usadha, I. G. N. R., Irawan, M. I., 2012, Seleksi Supplier Bahan Baku dengan Menggunakan Metode TOPSIS Fuzzy MADM (Studi Kasus PT Giri Sekar Kedaton Gresik). Jurnal Sains dan Seni POMITS, Vol 1, No.1, hal 1-6.

[4] Kuwumadewi, S., Hartati, S., Harjoko, A, Wardoyo, R., 2006, Fuzzy Multi Atribut Decission Making (Fuzzy MADM), Graha Ilmu, Yogyakarta.

[5] Shahanaghi, K., Yazdian, S. A., 2008, Vendor Selection Using a New Fuzzy Group TOPSIS Approach, Journal of Uncertain System, Vol 3, No 3, hal 221-231.

[6] Christian, R. A., Lad, R. K., Deshpande, A. W., Desai, N. G., 2008, Fuzzy MCDM Approach for Addressing Composite Index of Water and Air Pollution Potensial of Industries, International Journal of Digital Content Technology and its Application, Vol 2, No 2. 